\title{
Effect of Supplementing Different Levels of Turmeric Powder on Ileal Morphology in Laying Hens
}

\author{
Devvrat Kosti, D.S. Dahiya, Rajesh Dalal* and Vinus \\ Department of Animal Nutrition, Lala Lajpat Rai University of Veterinary and Animal \\ Sciences, Hisar - India \\ *Corresponding author
}

\section{A B S T R A C T}

\section{Keywords}

Laying hens, Villi height, Crypt depth, Histo-morphology, Turmeric

\section{Article Info}

Accepted:

10 June 2018

Available Online:

10 July 2018
To investigate the effects of using different levels of turmeric powder on ileal morphology in laying hens, one hundred and forty four, 22-weeks old White Leghorn hens were divided into 6 treatments with 4 replications and each replicate had 6 birds. Control group $\left(\mathrm{T}_{1}\right.$ ) was fed maize-soybean meal based diet without antibiotic while birds in $\mathrm{T}_{2}$ group were fed basal diet with antibiotic. In treatment groups $\mathrm{T}_{3}, \mathrm{~T}_{4}, \mathrm{~T}_{5}$ and $\mathrm{T}_{6}$ basal diet was supplemented with turmeric powder @ $0.25 \%, 0.50 \%, 0.75 \%$, and $1 \%$ respectively. After 16 weeks of the experimental period, one bird from each replicate was slaughtered and ileal sample were collected for morphometric analysis. The mean values of villi length, villi width and crypt depth in ileum of hens were ranged 943.81 to 1148.20 microns (villi length), 192.42 to 213.29 microns (villi width), 184.65 to 213.79 microns (crypt depth) respectively. There was significant $(\mathrm{P}<0.05)$ increase in the mean values of villi length from 947.94 microns in control group $\mathrm{T}_{1}$ to 1145.77 microns in treatment group $\mathrm{T}_{6}$ fed highest level of turmeric powder $(1.0 \%)$. Similarly there was significant $(\mathrm{P}<0.05)$ increase in villi width also from 194.78 microns in $\mathrm{T}_{1}$ to 213.29 microns in $\mathrm{T}_{6}(1.0 \%$ turmeric powder). There was significant $(\mathrm{P}<0.05)$ increase in crypt depth from 189.32 microns in $\mathrm{T}_{1}$ to 213.79 microns in $\mathrm{T}_{6}(1.0 \%$ turmeric powder). Thus, it can be concluded that dietary inclusion of turmeric powder reported a trend of improvement in villi length, villi width and crypt depth in gastrointestinal tract of hens.

\section{Introduction}

Poultry farming has undergone a paradigm shift in structure and operation, transforming itself from a mere backyard activity into a major commercial venture. India has emerged as the world's $2^{\text {nd }}$ largest poultry market with an annual growth of more than $14 \%$, producing 78.48 billion eggs and 3.04 million tonnes of broiler meat per year (Anonymous, $19^{\text {th }}$ Livestock census all India report, 2012). Poultry farming is, however highly susceptible to infectious diseases and antibiotics are used to treat diseases and used as antimicrobial growth promoters in poultry feed worldwide for many years. However, in order to avoid the possible risk of developing resistant pathogens, as well as to meet the public pressure of antibiotic-free animal products, the use of antibiotic in poultry diet was totally 
banned in European Community (Anonymous, 2003). Nevertheless, apart from preventing the potential hazard, the absence of antibiotic growth promoters in the diet has resulted in health problems in poultry (Casewell et al., 2003). In order to reduce the disadvantage of sub-clinical and clinical infections, the poultry and feed industries needs to find alternatives to antibiotic growth promoters. Compared with synthetic antibiotics or inorganic chemicals, plant-derived products have proved to be less toxic, residue free and thought to be ideal feed additives in food animal production (Wang et al., 1998). These natural dietary agents have drawn a great deal of attention from both the scientific community and the general public due to their various health prompting effects (Shukla and Singh, 2007). Turmeric a member Zingiberaceae family has been extensively used for the treatment of a variety of inflammatory conditions and other diseases. Curcuminoids have a wide spectrum of biological activities including antioxidant, antibacterial, antifungal, antiprotozoal, antiviral, anticoccidial and anti-inflammatory property (Masuda et al., 2001).

\section{Ethical approval}

The animal experiment was conducted in accordance with guidelines approved by the Institutional Animal Ethics Committee, 12/CPCSEA Dated 6.2.2017 in the Department of Animal Nutrition, Lala Lajpat Rai University of Veterinary and Animal Sciences, Hisar.

\section{Experimental design}

Completely Randomized Design was used as experimental design at uniform and standard management practices.

\section{Materials and Methods}

A total of one hundred and forty four single comb White Leghorn hens of commercial strain, 22 weeks of age, in the first phase of their production cycle with an average weight of $1764 \mathrm{~g}$ were randomly divided in to six treatment groups, having four replications with six birds in each replication. The birds were fed a maize-soybean meal based diet as per BIS standards (2007) in first treatment $\left(\mathrm{T}_{1}\right.$-negative control) and in second treatment the birds were fed with same diet added with antibiotic ( $\mathrm{T}_{2}$-positive control) and four different levels of turmeric powder were selected @ 0.25\%,0.50\%,0.75\% and 1.0\% in $\mathrm{T}_{3}, \mathrm{~T}_{4}, \mathrm{~T}_{5}$ and $\mathrm{T}_{6}$ respectively. Hens were fed the experimental diet for sixteen weeks beginning at 22 weeks of age and continued up to 38 weeks of age. All the feed ingredients were procured in one lot before the start of the experiment. The feed ingredients, feed additives and supplements used were maize, groundnut cake, soybean meal, rice polish, fish meal, mineral mixture, common salt, shell grit and vitamins. Feed additives and supplements were premixed and then mixed with weighed quantity of feed ingredients to make a homogenous mixture of rations. Chemical composition (\%DM basis) and metabolizable energy (ME, $\mathrm{Kcal} / \mathrm{Kg}$ ) of feed ingredients used in formulation of experimental diets are presented in the Table 1. The ingredients, composition and mixing rate of feed additives/supplements used in ration formulations are presented in Table 2. The laying hens were reared in deep litter system and hens were offered feed and water ad libitum. The data obtained were analyzed by analysis of variance with SPSS procedure and Least Significant Difference test with significance level of $95 \%$.

\section{Gastrointestinal morphology}

At the end, one bird from each replicate was slaughtered and ileal samples were collected for intestinal morphological examinations, cross-sections measuring $1 \mathrm{~mm}$ to $2 \mathrm{~mm}$ thick from ileum were prepared and enclosed in tissue cassettes. The tissues were fixed in $10 \%$ 
neutral buffered formalin over $24 \mathrm{~h}$ for each intestinal segment, a $5 \mu \mathrm{m}$ section was placed onto a glass slide and stained with alcian blue and hematoxylin-eosin. Slides were viewed under Fluorescent microscope and visual measurements were taken of the villous length ( $\mu \mathrm{m}$ distance from apex of villus to the junction of the villous and crypt), villous width and crypt depth $(\mu \mathrm{m}$ distance from the junction to the basement membrane of the epithelial cell at the bottom of the crypt).

\section{Statistical analysis}

Data was analysed statistically as described by Snedecor and Cochran (1994). Analysis of variance was used to study the differences among treatment means and they were compared by using Duncans Multiple Range Test 1955(DMRT) as modified by Kramer (1956).

\section{Results and Discussion}

\section{Intestinal morphology}

The mean values of villi length, villi width and crypt depth in ileum of hens were 947.94, $943.81,948.19,1142.44,1145.77$ and 1148.20 microns (villi length), 194.78, 192.42, 198.55, 206.85, 211.44 and 213.29 microns (villi width), 189.32, 184.65, 195.01, 198.99, 207.49 and 213.79 microns (crypt depth) are (Table 3) in treatment groups $\mathrm{T}_{1}, \mathrm{~T}_{2}, \mathrm{~T}_{3}, \mathrm{~T}_{4}, \mathrm{~T}_{5}$ and $\mathrm{T}_{6}$ respectively. The findings clearly indicate that, there was significant $(\mathrm{P}<0.05)$ increase in the mean values of villi length from 947.94 microns in control group $T_{1}$ to 1145.77 microns in treatment group $\mathrm{T}_{6}$ fed highest level of turmeric powder (1.0\%). Similarly there was significant $(\mathrm{P}<0.05)$ increase in villi width also from 194.78 microns in $\mathrm{T}_{1}$ to 213.29 microns in $\mathrm{T}_{6}(1.0 \%$ turmeric powder). Results of crypt depth were also same as above measures. There was significant $(\mathrm{P}<0.05)$ increase in crypt depth from 189.32 microns in $\mathrm{T}_{1}$ to 213.79 microns in $\mathrm{T}_{6}$ (1.0\% turmeric powder). Thus, it can be concluded that dietary inclusion of turmeric powder reported a trend of improvement in villi length, villi width and crypt depth in gastro-intestinal tract of hens. Figure 1 and 2 represents the mean values of villi length and crypt depth under different treatments. Figure $3,4,5,6,7$ and 8 depicts the histological morphometric analysis of villi length of ileal samples in $\mathrm{T}_{1}, \mathrm{~T}_{2}, \mathrm{~T}_{3}, \mathrm{~T}_{4}, \mathrm{~T}_{5}$ and $\mathrm{T}_{6}$ respectively.

Table.1 Chemical composition (\%DM basis) and metabolizable energy (Kcal/Kg) of feed ingredients the experimental diets

\begin{tabular}{|l|l|l|l|l|l|}
\hline Ingredients & CP & CF & EE & Ash & ME* \\
\hline Maize & 9.10 & 2.65 & 3.39 & 2.50 & 3309 \\
\hline Groundnut cake & 40.90 & 8.90 & 7.94 & 4.52 & 2596 \\
\hline Soybean Meal & 45.15 & 3.78 & 3.43 & 6.93 & 2230 \\
\hline Rice Polish & 12.20 & 4.69 & 14.78 & 12.83 & 2737 \\
\hline Fish Meal & 48.15 & 2.05 & 5.30 & 22.43 & 2240 \\
\hline
\end{tabular}


Table.2 Ingredient and chemical composition of ration for layers of control group

\begin{tabular}{|l|l|}
\hline Feed ingredients & Percentage (\%) \\
\hline Maize & 58 \\
\hline Groundnut cake & 10 \\
\hline Soybean Meal & 12 \\
\hline Rice Polish & 09 \\
\hline Fish Meal & 06 \\
\hline Mineral Mixture & 1.5 \\
\hline Salt & 0.5 \\
\hline Shell Grit & 03 \\
\hline Chemical composition & \% DM basis \\
\hline CP & 18.04 \\
\hline CF & 4.34 \\
\hline EE & 3.61 \\
\hline NFE & 66.21 \\
\hline Ash & 7.80 \\
\hline Metabolizable energy(Kcal/Kg) & 2697.17 \\
\hline
\end{tabular}

*Feed additive included Intermix Regular $10 \mathrm{~g}$, Meriplex d s $10 \mathrm{~g}$, Toxinil $100 \mathrm{~g}$ per $100 \mathrm{Kg}$ of ration.

*Intermix Regular - Each g contained vitamin A- 82,500 IU, vitamin $D_{3}-16,500 \mathrm{IU}$, vitamin B2- $50 \mathrm{mg}$ and vitamin $\mathrm{K}$ - $10 \mathrm{mg}$. (10 g/quintal)

*Meriplex- DS - Each g contained vitamin B1- $8 \mathrm{mg}$, vitamin $\mathrm{B}_{6}-16 \mathrm{mg}$, Niacin- $120 \mathrm{mg}$, vitamin $\mathrm{B}_{12}-80 \mathrm{mcg}$, Calcium D Pantothenate- $80 \mathrm{mg}$, vitamin $\mathrm{E}_{50}-80 \mathrm{mg}$ and Calcium- $88 \mathrm{mg}$. (10 g/quintal)

*Toxinil - Organic acid, mannon oligosaccharide (MOS), activated charcoal, sodium bentonite, HSCAS (hydrated sodium calcium allumino silicate), copper oxine, Bacillus subtilis (100 g/quintal)

*Mineral mixture - Mineral mixture for poultry: composition (w/w): moisture- 3\% (maximum), Calcium- 32\% (minimum), Phosphorus- 6\% (minimum), Manganese- $0.27 \%$ (minimum), Iodine- $0.01 \%$ (minimum), Zinc- $0.26 \%$ (minimum), Fluorine- $0.03 \%$ (maximum), Copper- 0.001\% (minimum) and Iron- $0.001 \%$ (minimum). (1.5 $\mathrm{kg} /$ quintal).

Table.3 Mean values of villi length, villi width and crypt depth in gastro-intestinal tract in layers under different treatments

\begin{tabular}{|l|l|l|l|}
\hline Treatments & $\begin{array}{l}\text { Villi length } \\
\text { (microns) }\end{array}$ & $\begin{array}{l}\text { Villi width } \\
\text { (microns) }\end{array}$ & $\begin{array}{l}\text { Crypt depth } \\
\text { (microns) }\end{array}$ \\
\hline $\mathbf{T}_{\mathbf{1}}$ & $947.94^{\mathrm{ab}} \pm 2.44$ & $194.78^{\mathrm{ab}} \pm 0.50$ & $189.32^{\mathrm{ab}} \pm 2.95$ \\
\hline $\mathbf{T}_{\mathbf{2}}$ & $943.81^{\mathrm{a}} \pm 0.27$ & $192.42^{\mathrm{a}} \pm 0.26$ & $184.65^{\mathrm{a}} \pm 1.12$ \\
\hline $\mathbf{T}_{\mathbf{3}}$ & $948.19^{\mathrm{b}} \pm 0.32$ & $198.55^{\mathrm{b}} \pm 0.97$ & $195.01^{\mathrm{b}} \pm 1.42$ \\
\hline $\mathbf{T}_{\mathbf{4}}$ & $1142.44^{\mathrm{c}} \pm 0.63$ & $206.85^{\mathrm{c}} \pm 1.14$ & $198.99^{\mathrm{bc}} \pm 1.87$ \\
\hline $\mathbf{T}_{\mathbf{5}}$ & $1145.77^{\mathrm{cd}} \pm 2.12$ & $211.44^{\mathrm{cd}} \pm 3.52$ & $207.49^{\mathrm{cd}} \pm 1.86$ \\
\hline $\mathbf{T}_{\mathbf{6}}$ & $1148.20^{\mathrm{d}} \pm 0.85$ & $213.29^{\mathrm{d}} \pm 0.28$ & $213.79^{\mathrm{d}} \pm 6.54$ \\
\hline
\end{tabular}

The mean values in same column with different superscripts differ significantly $(\mathrm{P}<0.05)$ 
Fig.1 Mean values of villi length (microns) in layers under different dietary treatments

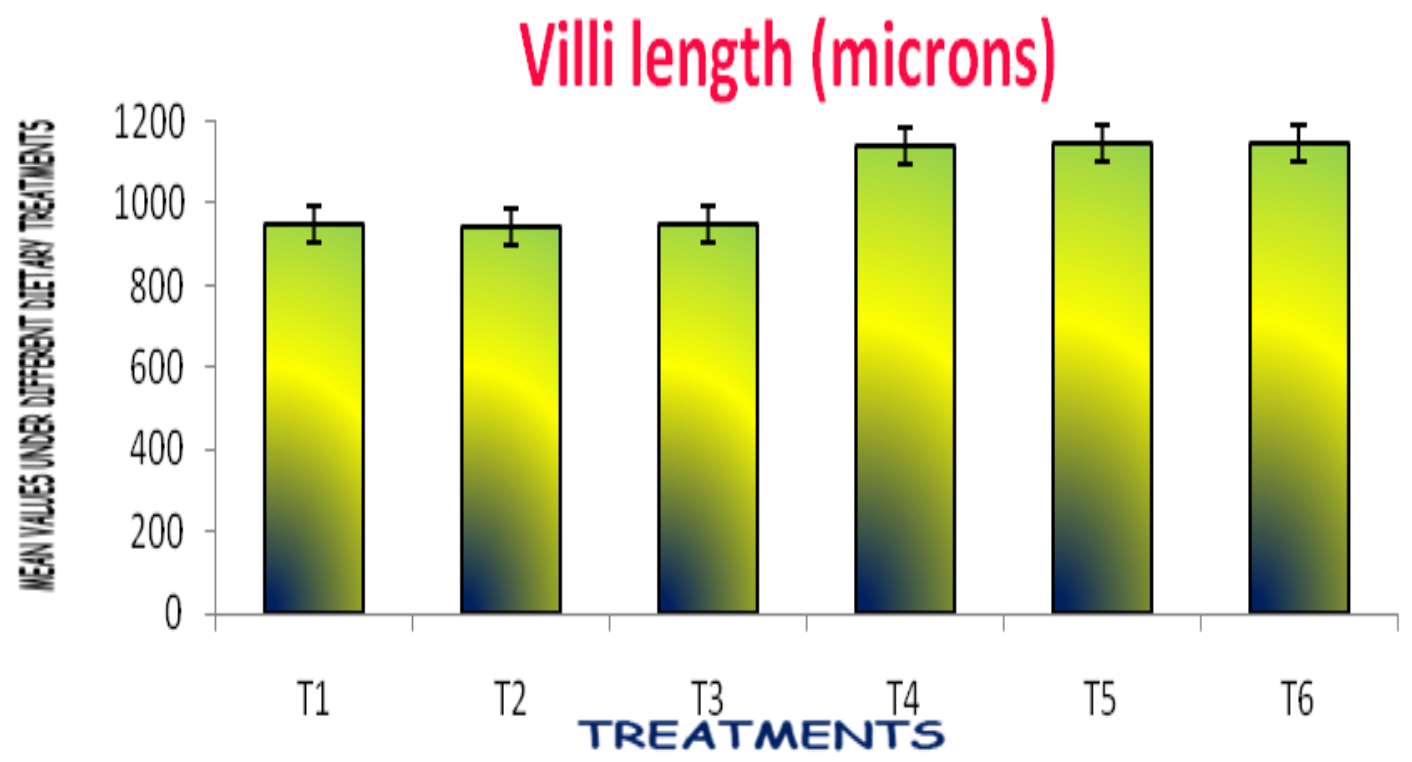

Fig.2 Mean values of crypt depth (microns) in layers under different dietary treatments

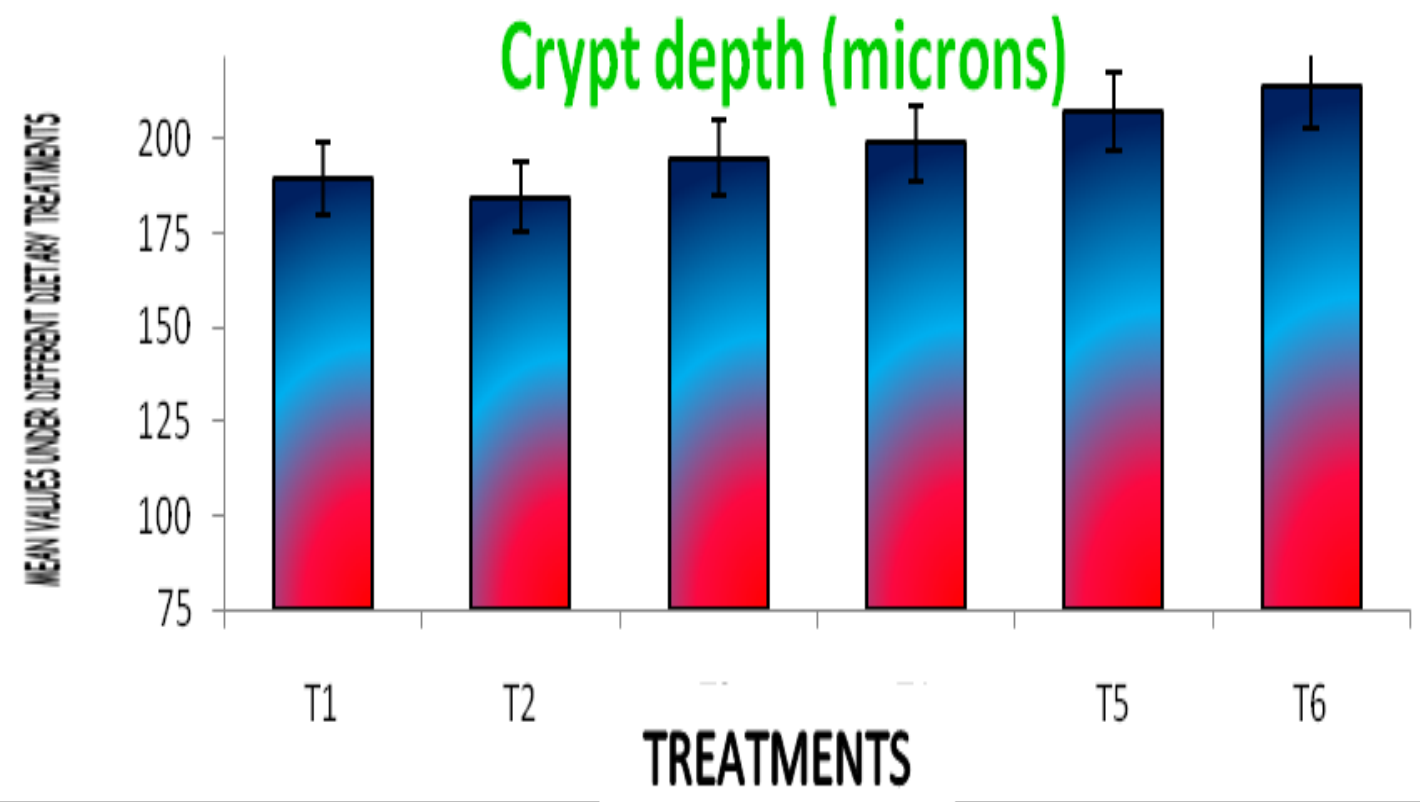


Fig.3 Villi length of ileum in group $\mathrm{T}_{1}$

Fig.4 Villi length of ileum in group $\mathrm{T}_{2}$

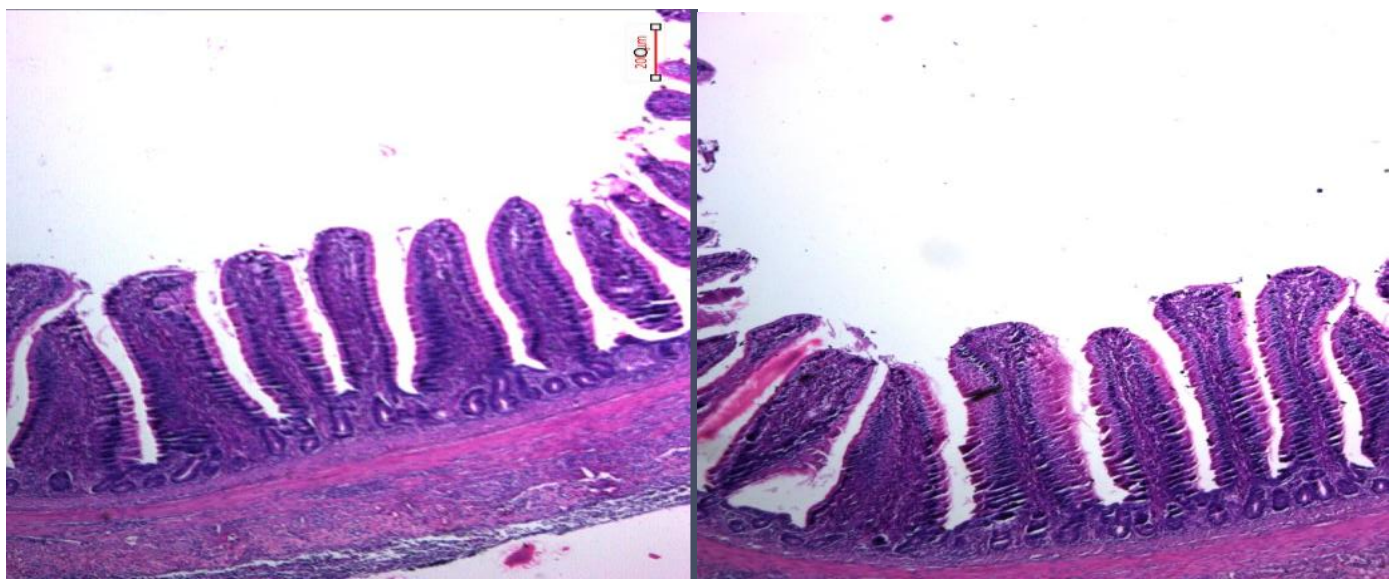

Fig.5 Villi length of ileum in group $\mathrm{T}_{3} \quad$ Fig.6 Villi length of ileum in group $\mathrm{T}_{4}$

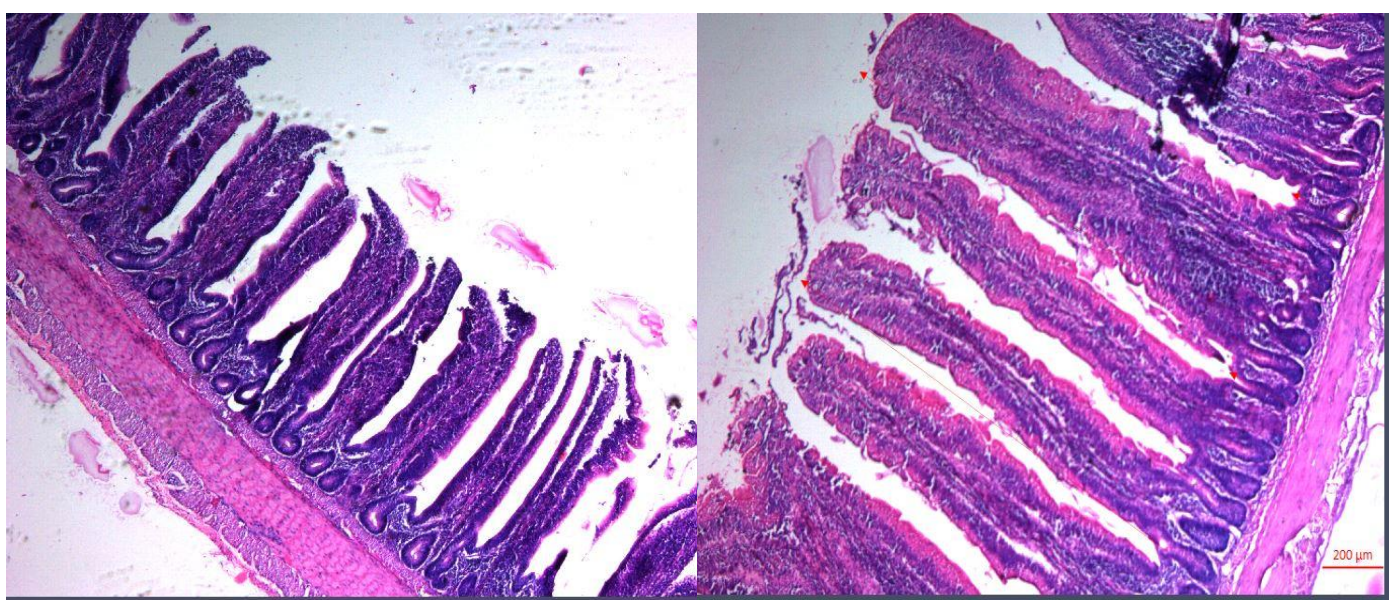

Fig.7 Villi length of ileum in group $\mathrm{T}_{5} \quad$ Fig.8 Villi length of ileum in group $\mathrm{T}_{6}$

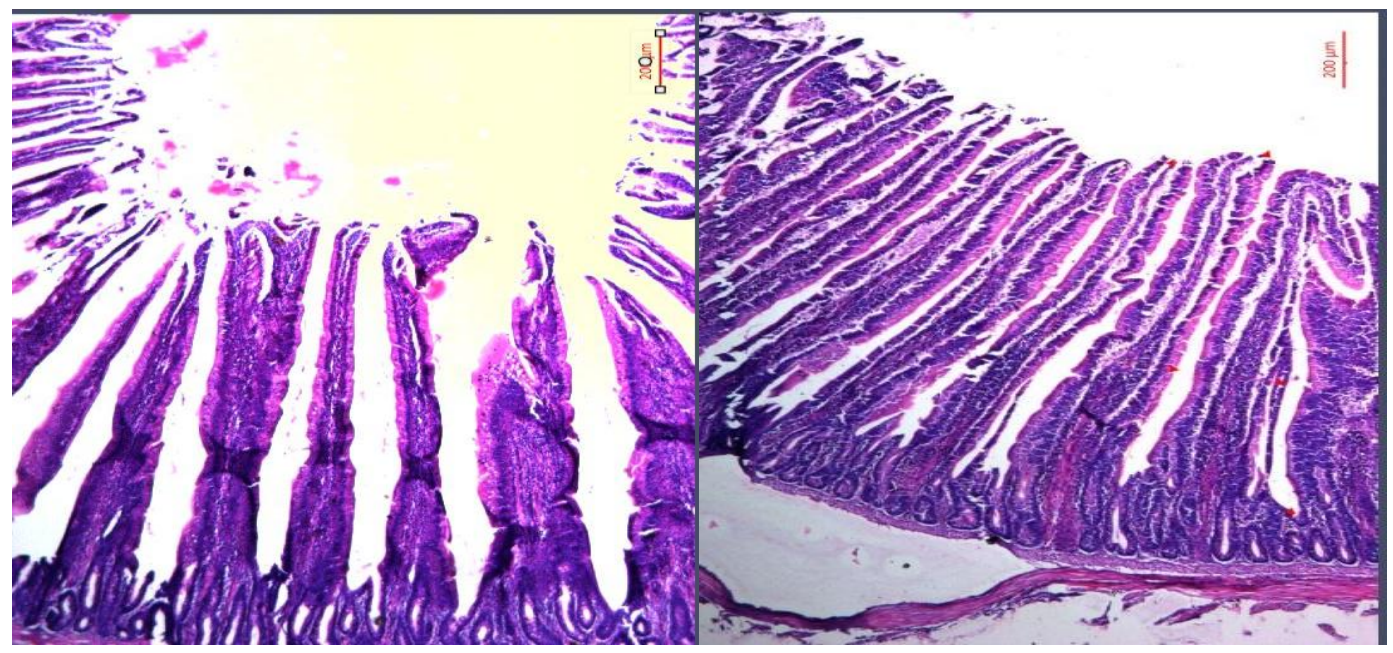


It may be due to the decreased bacteriological count of harmful microorganisms in the GI tract of birds; these microorganisms produce toxins which causes the sloughing off the intestinal epithelium. Turmeric powder neutralizes these toxins, so the intestinal epithelium renews itself. This ultimately results in increased villi length, width. The morphometric analysis results in the present study showed that the supplementation of antioxidants increased villi height and villi width. Also phenolic compounds administration like curcumin may reduce gut inflammation, improve digestibility of nutrients and metabolism (Giannenas et al., 2010). The villi:crypt depth ratio is an indicator of the likely digestive capacity of the small intestine. An increase in this ratio corresponds to an increase in digestion and absorption (Montagne et al., 2003). Increased intestinal villi height and the ratio of villi height to crypt depth is an indication of vast area for nutrient absorption and higher absorption function (Sieo et al., 2005). Thinning of the gastrointestinal walls tract may be due to the inhibition of the microbial production of polyamines and volatile fatty acids, known to increase enterocyte turnover rate and activity. This increased net energy committed to maintaining the luminal tissue comes at the expense of more productive purposes such as muscle accretion (Bedford, 2000).

These findings are in consistent agreement with Rajput et al., (2013) found that the duodenal villi heights were significantly higher in birds fed turmeric powder at level of $200 \mathrm{mg} / \mathrm{kg}$ at 21 and 42 day. The jejunum villi heights were significantly higher in birds fed turmeric powder at level of $200 \mathrm{mg} / \mathrm{kg}$ at 21 day and in birds fed turmeric powder at level of $100 \mathrm{mg} / \mathrm{kg}$ feed at 42 day. While, ileum villi height were significantly higher in birds fed turmeric at 150 and $200 \mathrm{mg} / \mathrm{kg}$ levels, in comparison with control and 100 $\mathrm{mg} / \mathrm{kg}$ level groups at 21 and 42 day. He also found that the duodenal villi width was significantly higher in birds fed turmeric at $200 \mathrm{mg} / \mathrm{kg}$ level at $21 \mathrm{day}$; while, at 42 day, control and group fed turmeric at $150 \mathrm{mg} / \mathrm{kg}$ exhibited more width. Furthermore, jejunum villi width at 42 day was significantly more in birds fed turmeric at $150 \mathrm{mg} / \mathrm{kg}$ and 200 $\mathrm{mg} / \mathrm{kg}$ level, as compared to control group. Namagirilakshmi et al., (2010) reported that the turmeric feeding to birds significantly increased $(\mathrm{P}<0.01)$ the intestinal villi length than control. This increase in the intestinal villi length could be attributed to the turmeric effect on gut health by reducing intestinal $\mathrm{pH}$, bacterial load and selectively increasing Lactobacillus count (Sieo et al., 2005). Contrary to these findings Rajput et al., (2013) stated that depth of intestinal crypts in curcumin supplemented groups was significantly less for all segments except for jejunum at 42 day of small intestine, as compared to those of control group. While, Kumar et al., (2017) stated that intestinal morphology in the duodenum, jejunum and ilium were not generally affected by BCS (black cumin seed).

In conclusion, the morphometric analysis results in the present study showed that the supplementation of antioxidants increased villi height and villi width, antioxidants present in turmeric powder may effectively scavenge the generated free radicals caused by stress, consequently resulting in improved ileal morphology. Also phenolic compounds like curcumin present in turmeric may reduce gut inflammation, improve digestibility of nutrients and metabolism. The villi: crypt depth ratio is an indicator of the likely digestive capacity of the small intestine. Increased intestinal villi height and the ratio of villi height to crypt depth is an indication of vast area for nutrient absorption and higher absorption function results in efficient production. 


\section{Acknowledgement}

The authors would like to acknowledge the help and support received from Department of Animal Nutrition and Animal Genetics and Breeding, LUVAS, Hisar for providing the lab facility, guidance and financial assistance.

Competing interests: The authors have no competing interests to declare.

\section{References}

Anonymous. (2003). Regulation (EC) No 1831/2003 of the European Parliament and of the Council of 22 September 2003 on additives for use in animal nutrition. Official J. European Union. 268: 29-43.

Anonymous. Govt. of India. 2012. 19 th $^{\text {th }}$ Livestock census all India report. Ministry of agriculture department of animal husbandry, dairying and fisheries. Krishibhawan, New Delhi.

Bedford, M. R. (2000). Exogenous enzymes in monogastric nutrition - their current value and future benefits. Anim. Feed Sci. and Technolo. 86(1): 1-13.

Cabuk, M., Bozkurt, M., Alcicek, A., Akbap, Y., and Küçükyýlmaz, K. (2006). Effect of a herbal essential oil mixture on growth and internal organ weight of broilers from young and old breeder flocks. S. Afr. J Anim. Sci. 36(2): 135141.

Casewell, M., Friis, C., Marco, E., McMullin, P., and Phillips, I. (2003). The European ban on growth-promoting antibiotics and emerging consequences for human and animal health. J. Antimicrobial Chemotherapy. 52(2): 159-161.

Duncan, D. B. (1955). Multiple range and multiple F tests. Biometrics. 11(1): 142.

Giannenas, I., Pappas, I. S., Mavridis, S.,
Kontopidis, G., Skoufos, J., and Kyriazakis, I. (2010). Performance and antioxidant status of broiler chickens supplemented with dried mushrooms (Agaricus bisporus) in their diet. Poult. Sci. 89(2): 303-311.

Kumar, P., Patra, A. K., Mandal, G. P., Samanta, I., and Pradhan, S. (2017). Effect of black cumin seeds on growth performance, nutrient utilization, immunity, gut health and nitrogen excretion in broiler chickens. J. The Sci Food and Agri.

Masuda, T., Maekawa, T., Hidaka, K., Bando, H., Takeda, Y., and Yamaguchi, H. (2001). Chemical studies on antioxidant mechanism of curcumin: analysis of oxidative coupling products from curcumin and linoleate. J. Agri. Food Chem. 49(5): 25392547.

Montagne, L., Pluske, J. R., and Hampson, D. J. (2003). A review of interactions between dietary fibre and the intestinal mucosa, and their consequences on digestive health in young nonruminant animals. Anim. Feed Sci. Tech. 108(1): 95-117.

Namagirilakshmi, S., Selvaraj, P., Nanjappan, K., Jayachandran, S., and Visha, P. (2010). Turmeric (Curcuma longa) as an alternative to in-feed antibiotic on the gut health of broiler chickens. Tamilnadu J. Vet. Anim. Sci. 6(3): 148-150.

Rajput, N., Muhammad, N., Yan, R., Zhong, X., and Wang, T. (2013). Effect of dietary supplementation of curcumin on growth performance, intestinal morphology and nutrients utilization of broiler chicks. The J. Poult. Sci. 50(1): 44-52.

Shukla, Y., and Singh, M. (2007). Cancer preventive properties of ginger: a brief review. Food Chem. Toxicol. 45(5): 683-690. 
Sieo, C. C., Abdullah, N., Tan, W. S., and Ho, Y. W. (2005). Influence of $\beta$ glucanase-producing Lactobacillus strains on intestinal characteristics and feed passage rate of broiler chickens. Poult. Sci. 84(5): 734-741.

Singh, K.S., and panda, B. 2002 poultry nutrition. 2nd edn. Kalyani publishers, new Delhi, India

Snedecor, G.W., and Cochran W.G. (1994). Statistical Methods, $7^{\text {th }}$ edn. Oxford and IBH.

SPSS, I. (2012). Statistics for windows, version 20.0. IBM Corp., Armonk, New York.

Visek, W. J. (1978). The mode of growth promotion by antibiotics. J. Anim. Sci.
46(5): 1447-1469.

Wang, R., Li, D., and Bourne, S. (1998). Can 2000 years of herbal medicine history help us solve problems in the year 2000. In Alltechs annual symposium. 14: 168-184.

Yoo, J., Yi, Y. J., Koo, B., Jung, S., Yoon, J. U., Kang, H. B., and Heo, J. M. (2016). Growth performance, intestinal morphology, and meat quality in relation to alpha-lipoic acid associated with vitamin $\mathrm{C}$ and $\mathrm{E}$ in broiler chickens under tropical conditions. Revista Brasileira de Zootecnia. 45(3): 113-120.

\section{How to cite this article:}

Devvrat Kosti, D.S. Dahiya, Rajesh Dalal and Vinus. 2018. Effect of Supplementing Different Levels of Turmeric Powder on Ileal Morphology in Laying Hens. Int.J.Curr.Microbiol.App.Sci. 7(07): 1524-1532. doi: https://doi.org/10.20546/ijcmas.2018.707.179 